\title{
PERUBAHAN SOSIAL DAN EKONOMI MASYARAKAT AKIBAT PERKEBUNAN KELAPA SAWIT
}

\author{
Ismail Ruslan ${ }^{1}$
}

\section{PENDAHULUAN}

Pembangunan di bidang pertanian dan perkebunan pada tahapan tertentu akan membuka ruang pengembangan bisnis agribisnis dan investasi pihak ketiga di suatu wilayah. Masuknya investor pada wilayah bisnis perkebunan (baca: sawit) akan menjadi stimulus berdirinya pabrik-pabrik pengolahan kalapa sawit dan membuka lapangan pekerjaan bagi masyarakat lokal maupun "pendatang".

Berdirinya perusahaan perkebunan kelapa sawit berdampak terhadap perekonomian nasional maupun perekonomian masyarakat lokal (baca: Kabupaten Landak atau provinsi Kalimantan Barat). Pendapatan Asli Daerah (PAD) akan meningkat, diperoleh dari pajak perusahaan dan pabrik. Perubahan ekonomi juga dirasakan dengan tumbuhnya pusat-pusat ekonomi dan maraknya bisnis lainnya, seperti perumahan.

Pembangunan perkebunan kelapa sawit juga berdampak terhadap perubahan sosial masyarakat.Tingkat pendidikan dan kesehatan masyarakat lokal menjadi lebih baik, angka putus sekolah berkurang dan asupan gizi bagi anak-anak dapat dipenuhi.

Namun, selain sisi positif bagi sosial ekonomi masyarakat, pembangunan perkebunan kelapa sawit dan pertanian juga memiliki dampak negatif. Perubahan itu tampak pada mulai hilangnya marwah institusi lokal (lembaga adat) masyarakat lokal. Masyarakat lebih berpikir pragmatis dan hedonis, tata cara hidup tidak lagi merujuk pada tata aturan adat budaya setempat.

Perkebunan kelapa sawit juga mempengaruhi hingga ke institusi keluarga, komunikasi orang tua dan anak sudah mulai berkurang. Pendidikan di keluarga lebih didominasi oleh teknologi dan media (media masa maupun media sosial) dari pada orang tuanya sendiri.

Kekerabatan masyarakat adat mulai longgar. Ritual adat sebagai media religius dan sosial berubah menjadi lebih pada serimonial dan lebih kental aspek pariwisata. Masyarakat lokal kehilangan identitas dan jati diri, segala yang terkait dengan warisan sudah kehilangan maknanya.

Dampak negatif masuknya bisnis perkebunan kelapa sawit juga terjadi pada aspek lingkungan. Dahulunya masyarakat adat dalam memenuhi hidupnya bergantung kepada alam dan hutan, termasuk berinteraksi dengan penciptanya "Jubata", dipercaya bahwa keseimbangan alam merupakan media berkomunikasi dengan penciptanya. Saat ini hutan adat, berfungsi hutan lindung telah berubah menjadi hamparan kebun kelapa sawit.

Gelombang perkebunan sawit tidak mampu dibendung oleh masyarakat lokal maupun Pemerintah Daerah. Investasi perkebunan kelapa sawit sudah menjangkau pemilik modal besar dan pejabat-pejabat. Pemilik agribisnis kelapa sawit lebih didominasi pemilik modal besar berkolaborasi dengan pemerintah pusat, walaupun ada juga pejabat daerah yang memiliki lahan kelapa sawit.

Masyarakat lokal telah merasakan perubahan sosial dan ekonomi, meningkatnya pendapatan asli daerah, tidak diiringi pemerataan bagi masyarakat lokal. Kesuksesan ekonomi

1 Dosen Sosiologi Ekonomi Institut Agama Islam Negeri Pontianak 
lebih didomonasi oleh “pendatang”. Pertanyaannya, sawit di Landak untuk mensejahterakan siapa??

Pembangunan selain memiliki nilai positif pasti menyisakan persoalan sosial dan ekonomi. Perubahan telah terjadi bagi masyarakat lokal dan pendatang seperti aspek ekonomi meningkat, pendidikan dan aspek kesehatan lebih baik. Namun dampak negatif juga muncul kepermukaan, dan mempengaruhi kehidupan masyarakat lokal dan lingkungan.

Beberapa penelitian terdahulu. lebih banyak mengkaji pada persoalan-persoalan teknis yang dibicarakan di wilayah kelapa sawit. Peneliti itu membincangkan tentang pencarian bibit unggul (Chairan :1991; Chaniago, F. :1988; Anon :1988); serangga yang merusak tanaman kelapa sawit (Pardede D :1990); teknis perawatan kebun (Lubis S, Poeloengan Z dkk :1990; Kosasih :1988); pengolahan kelapa sawit (Hasni H; Torar DJ dkk :1987; Pusat Perpustakaan dan Penyebaran Teknologi Pertanian :1986).

Penelitian lainnya mengkaji tentang pola kerja sama antara PTPN dan masyarakat (Anon :1989); sejarah perkembangan perkebunan kelapa sawit (Pangudijatno: 1988); respon masyarakat terhadap hasil olahan kelapa sawit (Amrizal :1987).

Penelitian ini berbeda, pertama, problem penelitian yang dikaji lebih melihat perubahan ekonomi pada masyarakat lokal dan juga ekonomi "pendatang" akibat masuknya perkebunan kelapa sawit sejak tahun 1980. Perubahan aspek ekonomi masyarakat terlihat jelas mulai dari individu, ekonomi keluarga dan ekonomi daerah. Kedua, penelitian ini juga mendalami perubahan sosial masyarakat lokal yakni perubahan pola berladang menjadi petani sawit (pola perkebunan) dan perubahan eksistensi lembaga adat yang sudah ada sejak puluhan tahun lalu.

\section{PERUBAHAN SOSIAL MASYARAKAT}

1. Ladang Bepindah-pindah

Sejarah awal masyarakat lokal (baca: orang Dayak) untuk memenuhi kebutuhan hidup keluarga atau kelompok dengan cara berladang. Setiap keluarga atau kelompok bertahan hidup dengan cara menanam padi di bukit-bukit dan berpindah-pindah dari satu tempat ke tempat lainnya. Lahan yang dipergunakan untuk berladang awalnya adalah hutan, mereka membuka hutan dengan cara membakar atau ditebang selanjutnya ditanami padi ${ }^{2}$.

Untuk memberikan tanda kepemilikan atas lahan atau tanah (ladang) didasarkan kepada siapa orang yang pertama kali membuka hutan. Di pinggir lahan biasanya ditanami pohon-pohon keras seperti pohon durian, nangka, cempedak, dan lainnya. Hal ini dimaksudkan sebagai tanda atau batas antara lahan satu dengan lainnya. Masyarakat lokal juga memberikan batas tanah dengan diberi parit. Cara ini sangat efektif, dan disepakati oleh masyarakat setempat, indikasinya, lahan yang sudah dibuka dan ditanami tidak dimiliki oleh orang lain. Inilah yang dikenal dengan istilah kearifan lokal (local wisdom).

Namun untuk kepemilikan lahan, masyarakat lokal sudah banyak yang memiliki sertifikat tanah sebagai tanda hak milik. Pola Perkebunan Inti Rakyat (PIR) menggaransi bahwa setiap orang yang sudah memiliki lahan sawit akan diberikan sertifikat hak milik.

Ikatan kekerabatan masyarakat lokal (orang Dayak) sangat kuat. Semua pekerjaan dilakukan secara bersama-sama, mulai dari membuka hutan, bercocok tanam padi, berburu binatang dan lainnya. Walaupun sering juga terjadi konflik antara sub etnik Dayak yang berdomisili di pedalaman.

2 . Baca hasil penelitian Yusriadi, Hermansyah dan Ismail Ruslan dkk (2012). Pengetahua Tradisional Masyarakat Dayak (Studi Atas Masyarakat Benuaq di Tanjung Isuy Kalimantan Timur). Pontianak: Balai Pelestarian Nilai Budaya Pontianak. 
Untuk tempat tinggal orang Dayak membangun "rumah betang" atau rumah panjang. Ukuran rumah panjangnya bisa mencapai +-40 meter atau lebih. Setiap rumah betang memiliki 5-6 kamar (lebih), masing-masing kamar ditempati oleh satu kepala keluarga.

Sejak dikenalkan perkebunan sawit, pola hidup berkelompok dengan menempati rumah panjang mulai berubah. Salah satu faktor perubahan itu, sejak masyarakat lokal (Dayak) memperoleh rumah dan lahan dari PTPN. Masing-masing kepala keluarga (KK) diberi hak untuk mengelola 1 kapling (2 hektar) lahan sawit.

Namun petani plasma (masyarakat lokal) sebagai pemilik awal lahan perkebunan banyak yang lebih memilih kembali ke kampung asalnya. Awalnya PTPN XIII membuka lahan sawit di dusun Jamai dengan konsep PIR. Penduduk dusun Jamai diberikan lahan sawit setiap keluarga 1 kapling (2 hektar), dilengkapi dengan rumah untuk setiap kepala keluarga dan lahan pekarangan.

Namun perjalanan waktu, penduduk dusun Jamai banyak yang kembali ke kampung halamannya. Alasan yang dikemukakan bahwa mereka tidak dapat meninggalkan rumah asal, kampung dan sanak keluarga. Hal ini berakibat rumah yang diberi oleh PTPN kosong, dan banyak yang sudah roboh. Hingga tahun 2014, dari $264 \mathrm{KK}$ pemilik rumah hanya tersisa 35 KK yang menempati rumah pembagaian PTPN XIII.

\section{Masa Perkebunan Karet}

Karet merupakan jenis tanaman yang awalnya dikembangkan oleh Inggris. Kemudian jenis tanaman ini diuji coba untuk ditanam di Singapura dan Malaysia. Diduga, biji karet dibawa ke Kalimantan Barat oleh orang-orang Dayak yang sebagain besar memiliki hubungan darah dengan Dayak yang ada di Malaysia. Proses ini diperkirakan terjadi sekitar abad 19. Kemudian Masyarakat lokal (orang Dayak) di Kalimantan Barat mengembangkan karet sebagai sumber tanaman yang dapat dijual kepada pihak lain.

Awalnya, kebutuhan masyarakat lokal diperoleh dari sumber daya alam yang tersedia, ikan di Sungai Kapuas, babi, buah, sayur dan sebagainya. Untuk memenuhi kebutuhan lain seperti garam dan gula masyarakat lokal harus membeli kepada pihak lain. Untuk menghasilkan uang sebagai alat tukar, maka orang Dayak memelihara karet dan mengambil getahnya untuk dijual.

Pada masa perkebunan karet ini, orang Dayak masih melakukan pertanian berpindahpindah. Namun hutan yang dibuka untuk lahan pertanian (ladang) sudah terbatas. Hal ini terjadi karena, setiap kali membuka lahan pertanian, selalu ditanami karet yang berfungsi sebagai tanda kepemilikan dan sebagai jenis tanaman produktif.

Untuk memenuhi kebutuhan hidupnya, orang Dayak tidak terlalu bergantung pada kebun karet. Mereka masih mengandalkan ladang pertanian, berburu, dan menangkap ikan. Pohon karet juga baru dapat disadap setelah berumur 8 tahun. Masyarakat tidak dibatasi oleh waktu untuk menyadap karet, kapanpun waktunya dapat dilakukan, karena karet tidak akan rusak dan getahnya akan semakin banyak.

Kekurangan dari tanaman karet ini sangat tergantung dari kondisi cuaca. Jika pada musim panas, pohon karet akan menghasilkan banyak getah karet dan harga jual juga tinggi. Sebaliknya, jika musim hujan tiba, petani karet tidak dapat menyadap getah, karena getah karet akan berkurang sebagaimana pada musim kemarau.

Ketergantungan kepada musim panas dan hujan, membuat masyarakat selalu berkeluh kesah saat musim hujan tiba. Dampaknya, masyarakat tidak dapat bekerja menyadap karet, dan ekonomi keluarga akan semakin sulit. 


\section{Masa Perkebunan Sawit}

Berbeda dengan karet, pemilik kebun kelapa sawit ditentukan disiplin tinggi. Siklus hidup Kelapa sawit sangat teratur. Pada saat pembibitan dan penanam mulai dilakukan, maka sejak saat itu pekerjaan memelihara sawit sudah dilakukan. Seperti, membersihkan lahannya, pemberian pupuk, obat hama, hingga masa panen. Memasuki masa panen sejak tahun ke 3, maka buah yang sudah siap panen harus dijual ke pabrik dan diolah menjadi CPO dalam waktu 24 jam. Jika terlambat, maka buah sawit akan membusuk dan kualitasnya akan turun.

Sejarah penanam sawit di Kalimantan Barat tidak dapat dilepaskan dari peran penting yang diemban oleh PT. Perkebunan Nasional (PTPN XIII). Pada tahun 1980an, PTPN diberi tanggung jawab oleh Pemerintah RI untuk membuka lahan kelapa sawit, dengan pola kerja sama masyarakat.

Pemerintah Provinsi Kalimantan Barat, menempatkan proyek perkebunan kelapa sawit ini di Kabupaten yang memiliki luas lahan minimal 8000 Hektar dan berada di wilayah satu kawasan. Angka ini menjadi syarat pemerintah pusat untuk pembukaan lahan perkebunan sawit ini.

Perkebunan sawit ditempatkan di Kabupaten Landak khususnya di Kecamatan Ngabang ( desa Amboyo Inti, Amboyo Selatan, Amboyo Utara Desa Tamiyang Sawit); dan Kabupaten Sanggau (Kecamatan Perindu, Kecamatan Kembayan, Kecamatan Meliyau terdiri dari desa Meliyau, desa Sungai Dekan, desa Rimba Belian, desa Gunung Mas), serta tanaman karet di Kabupaten Sintang.

Perkembangan sawit di Kalimantan Barat merupakan program pemerintah dengan pola perkebunan inti dan rakyat. Program ini dibiayai oleh bank dunia dengan pola kredit yang ditanggung oleh Pemerintah Indonesia. Tujuan dari program ini untuk memberdayakan ekonomi masyarakat di beberapa wilayah di Indonesia, seperti di Sumatera Utara, Riau, Kalimantan Timur, Selatan dan Kalimantan Barat dengan pola Perkebunan Inti Rakyat $(\mathrm{PIR})^{3}$.

Pola Perkebunan Inti Rakyat awalnya berjalan lancar, masyarakat merasakan ada perhatian dari pemerintah terhadap kehidupan perekonomian mereka. Dengan luas wilayah $8000 \mathrm{H}$, setiap kepala keluarga (KK) akan menerima 1 kapling $(2 \mathrm{H})$. Artinya, pada saat pembukaan lahan sawit diperlukan 4000KK untuk menggarap perkebunan sawit tersebut.

Proyek ini berjalan baik, perkebunan kelapa sawit tersebut dikerjakan oleh PTPN, mulai dari pembukaan lahan, jalan, penyediaan bibit, penanaman, pembibitan, hingga panen pun dibantu oleh perusahaan perkebunan nasional. Ketika memasuki usia tahun ke

3 Pola PIR yang diterapkan oleh PTPN XIII merupakan adopsi dari bentuk kerja sama yang dilakukan oleh Pemerintah Malaysia. Pada tahun 1967an, setelah Malaysia merdeka, negara ini mengalami persoalan politik yakni pertarungan dengan ideologi komunis yang masuk ke wilayah ini. Pemerintah Malaysia yang dikuasai oleh partai UMNO kemudian merumuskan konsep FELDA (Federal Land Development Anthonith) untuk memutus pengaruh ideologi komunis dengan cara meningkatkan ekonomi dan kesejahteraan penduduk. Penduduk yang dituju adalah kelompok Melayu yang bermukim di wilayah pedesaan atau perkampungan. Selain ideologi komunis yang masuk ke wilayah ini, kelompok Melayu juga dipengaruhi oleh PAS (Partai Islam). Pemerintah Indonesia dibawah kepemimpinan Soeharto (sejak tahun 1966) mengalami persoalan yang sama, pertaruangan dengan komunisme dan Islamisme. Konsep FEODA yang dikembangkan di Malaysia, kemudian diadopsi dengan nama Perkebunan Inti Rakyat (PIR) dengan cara meningkatkan taraf ekonomi dan kesejahteraan masyarakat Indonesia. Pada pemilu tahun 1970an, Partai Golkar sebagai Partai Pemerintah berkuasa mengalami kekalahan di provinsi Aceh dan Jakarta. Sehingga konsep PIR digunakan tidak hanya untuk meningkatkan taraf hidup ekonomi masyarakat namun juga menanamkan pengaruh partai Golkan kepada masyarakat. 
3 tanaman sawit ini, maka PTPN menyerahkan semua pengelolaan lahaan sawit tersebut kepada masing-masing kepala keluarga. Hubungan masyarakat lokal dengan perusahaan tetap berlangsung, karena hasil panen kelapa sawit harus dijual kepada perusahaan. Hingga tahun 2010, hubungan ini masih terjaga baik.

Pada tahun 2006/2007, gubernur Kalimantan Barat mengundang investor untuk menanamkan modalnya di wilayah ini. Sejak saat itu, ada 56 perusahaan yang mendaftar untuk investasi. Namun daam perjalananya, +- 20 perusahaan yang serius ikut terlibat di dalam bisnis sawit, selebihnya tidak jelas. Ada yang hanya mengurus sampai mendapatkan surat izin kemudian menjualnya kepada pihak lain, ada juga yang tidak menfollow up bisnis ini.

Pada tahun 2008, negara-negara eropa mensyaratkan bahwa sawit harus memenuhi standar RSPO. Sejak saat itu, maka berdirilah perusahaan sawit swasta seperti PT. Wilmar di Kecamatan Pahauman dan SMS (di Kecamatan Sebangki). Dalam catatan pemerintah daerah Kabupaten Landak, mulai 1-2 tahun ke depan akan berdiri beberapa perusahaan sawi swasta lainnya, seperti: PT. IGP (di Kecamatan Ngabang), PT. SSS (di Kecamatan Ngabang), PT. LIP (Kecamatan Jelipo, PT Wilmar 2(di Kecamatan Ngabang) dan PT. DSM (di Kecamatan Ngabang). ${ }^{4}$

Keinginan pemerintah Indonesia termasuk pimpinan di Kalimantan Barat untuk mendorong pertumbuhan ekonomi masyarakat lokal (khususnya di Kecamatan Ngabang) tidak mudah dan berjalan penuh liku. Awalnya program ini berjalan sesuai apa yang direncanakan. Pola perkebunan sawit yang dirumuskan oleh PTPN XII, 80\% lahan sawit dikelola oleh perusahaan mulai dari pembibitan hingga pemasaran berjalan baik dan menguntungkan.

Namun perkebunan rakyat atau dikenal dengan plasma ${ }^{5}$ dimana masyarakat lokal mengelola perkebunan sawit sendiri menemui persoalan serius. Di samping persoalan ekonomi, temuan di lapangan menunjukkan banyak persoalan sosial yang muncul.

Pertama, awalnya semua tanah perkebunan merupakan milik dan dalam kekuasaan masyarakat lokal, sebagai tanah adat merupakan warisan dari orang tua atau leluhurnya. Konsep kepemilikan lahan ini hanya dibatasi untuk pengelolaan saja, pada saat yang bersamaan lahan tersebut mestinya dapat digunakan oleh keluarga besar atau kelompok secara bersama-sama.

Sejak dikenalkannya perkebunan sawit, terjadi perubahan hak kepemilikan lahan. Saat ini, setiap orang dari masyarakat lokal "hanya" memiliki 2 hektar dibuktikan dengan sertifikat dari pemerintah, dengan catatan jika yang bersangkutan telah melunasi "kredit" terhadap bank. Padahal awalnya lahan tersebut adalah milik kelompok atau tanah adat leluhur mereka.

Kedua, masyarakat lokal (Dayak) dikenal dengan pola hidup mengelompok. Pola ini memberikan pesan bahwa masyarakat lokal (Dayak) memiliki sistem kekerabatan sangat kuat. Hal ini ditunjukkan dengan hidup berkelompok di dalam 'rumah betang' . Pola yang

4 Informasi tentang sejarah perkebunan sawit di Kabupaten Landak (kerja sama antara PTN XIII dengan masyarakat lokal diperoleh dari salah satu pejabat di Kabupaten Landak. Sebelum posisinya saat ini, ia merupakan salah satu Camat di Kabupaten Landak yang terlibat langsung dan berpengalaman dalam seluk beluk bisnis perkebunan kepala sawit. Ia adalah penduduk lokal yang sukses dalam karier di birokrasi dan bisnis. Salah satu bisnis yang sedang dikembangkan adalah sarang walet.

5 Plasma adalah istilah lain yang digunakan oleh pihak PTPN dan masyarakat yakni masyarakat lokal (petani sawit) ikut terlibat dalam pengelolaan perkebunan sawit mulai tahun ke 3 penanaman. Sejak saat itu, kebun di rawat, dipupuk dan dipanen oleh petani.

6 Rumah betang adalah rumah yang dibuat oleh orang Dayak untuk tempat tinggal 10 kepala 
diterapkan oleh pemerintah dengan memberikan setiap kepala keluarga hak pengelolaan kebun sejumlah 1 kapling (2 Hektar) merupakan upaya individualisasi terhadap hak adat. Pola hidup kolektif tidak hanya menjaga eksistensi masyarakat lokal namun juga keberlanjutan hidup adat budaya mereka.

Ketiga, masyarakat lokal pada awalnya memiliki hak mengelola terhadap semua tanah adat, sejak munculnya pola ini, masyarakat dibatasi untuk bertahan hidup dengan radius 2 hektar.

Keempat, berubahnya fungsi lahan dari ladang padi, perkebunan karet menjadi perkebunan sawit merusakan tatanan hidup dan hubungan spiritulitas kelompok masyarakatnya. Masyarakat lokal (Dayak) memiliki aturan, setiap aktivitas akonomi dan sosial selalu melakukan ritual, termasuk pembukaan lahan.

Kelima, masyarakat lokal yang awalnya hidup mengelompok, pengerjaan ladang dan kebun secara bersama-sama dengan tetap mempertahankan adat, mengalami perubahan dari berladang dan menanam padi dan karet dengan berpindah-pindah membuat masyarakat lokal meninggalkan kampung halaman pertamanya.

Perubahan pola tanaman dari ladang berpindah menjadi menetap dan jenis tanaman karet dan padi yang biasa dilakukan oleh masyarakat lokal menjadi pola menetap tidak berjalan mulus. Sosialisasi pihak perusahaan tentang keunggulan sawit dengan nilai jual yang tinggi mengalami dinamika luar biasa. Awalnya, masyarakat lokal sangat berharap sawit mampu memberikan perubahan ekonomi karena dikenalkan sebagai jenis tanaman yang bernilai tinggi, namun dalam perjalananya mengalami pasang surut.

Pada tahun 1999 saat terjadi krisis moneter, masyarakat lokal yang sudah menanam sawit, mengalami shok dengan turunnya harga jual sawit. Rendahnya nilai jual ini tidak sebanding dengan ongkos produksi. Kejadian ini membuat banyak petani sawit merugi. Masyarakat lokal mengalami trauma, ada yang tetap bertahan namun banyak juga diantara mereka yang menjual lahan sawitnya kepada pihak lainnya.

Kekecewaan terhadap janji kesejahteraan yang disosialisasikan oleh pemerintah tidak dapat diwujudkan dalam rentang waktu 1 atau 2 tahun, seperti layaknya menanam padi yang dapat dipanen 2 kali atau lebih dalam waktu tahun. Berbeda dengan sawit, masa pembukaan hutan menjadi lahan perkebunan, penanaman bibit, pemupukan memerlukan waktu 3 tahun. Masa panen kelapa sawit baru dapat dilakukan pada usia kelapa sawit lebih dari 3 tahun.

Faktor-faktor inilah yang mendorong sebagian besar petani sawit (masyarakat lokal) menjual kebunnya kepada pihak lain, diantara pembeli dari kalangan karyawan PTPN XIII, 'pendatang' dari luar Kabupaten Landak. Pada saat ini, kepemilikan kebun kelapa sawit inti lebih didominasi oleh "pendatang" dari pada masyarakat lokal.

\section{Hubungan Sosial Masyarakat Lokal Dengan Pendatang}

Interaksi sosial masyarakat yang berdomisili di sekitar wilayah perkebunan kelapa sawit PTPN XIII dan "pendatang" sangat dinamis, mengalami pasang surut. Ada kalanya berlangsung harmonis, kadang juga terjadi gesekan antara keduanya.

Hubungan Harmonis antara masyarakat lokal dan perusahaan terjadi sejak awal

keluarga atau lebih. Setiap kampung Dayak memiliki rumah betang ini. Bentuknya memanjang hingga puluhan meter, dan dibangun tinggi +- 5 sampai 10 meter. Bentuk rumah seperti ini sebagai pertahanan dari serangan kelompok lain dan serangan hewan buas dan liar. Segala aktivitas kelompok (sub etnik) dilakukan di sekitar rumah ini. Dengan pola seperti ini kekerabatan dan solidaritas kelompok ini akan selalu terjaga. Jika ada ancaman dari kelompok lain, akan dihadapi bersama. 
pembukaan lahan perkebunan kelapa sawit, tahun 1980an. Kesepakatan kedua belah pihak untuk bekerja sama dalam pembukaan dan penanaman kelapa sawit. PTPN bertanggung jawab untuk menanam kelapa sawit, mulai dari pembukaan lahan perkebunan (pembersihan lokasi dari semak belukar), penanaman bibit kelapa sawit, pemberian pupuk, perawatan. Tanggung jawab perusahaan terhadap perkebunan masyarakat (plasma) berlangsung selama 3 tahun. Segala pembiayaan yang ditimbulkan dari aktivitas perusahaan sebagai bentuk komitmen ditanggung oleh perusahaan milik negara tersebut.

Masyarakat lokal juga dibebankan tanggung jawab yakni dengan menyerahkan lahan "leluhur" untuk ditanami kelapa sawit. Mereka akan diberi sertifikat tanah atau kebun kelapa sawit seluas 2 hektar (1 kapling), dengan syarat membayar secara kredit kepala perusahaan (bank yang ditunjuk). Selama 3 tahun, masyarakat lokal tidak diberi kewajiban untuk merawat kebun kelapa sawit, semua pekerjaan tersebut dilakukan oleh PTPN.

Pada saat kelapa sawit memasuki memasuki usia 3 tahun dan sudah dapat menghasilkan buah, masyarakat sebagai petani kelapa sawit berkewajiban merawat sendiri kebun tersebut, serta segala hasil buah sawit wajib dijual kepada PTPN.

Saat ini, petani plasma ada yang tidak menjual hasil panen sawitnya kepada perusahaan. Mereka beralasan bahwa sistem pembayaran yang dijalankan oleh perusahaan mempersulit petani sawit, karena membayar hasil sawit dengan masa waktu satu bulan ke depan. Selain PTPN Ngabang yang membei kelapa sawit, juga terdapat beberapa perusahaan yang bersedia membeli buah kelapa sawit milik petani plasma. Beberapa petani plasma menjual buah sawit kepada pabrik pihak ketiga dengan sistem pembayaran tunai. Berapa pun jumlah buah yang akan dijual, pabrik swasta bersedia membelinya.

Dinamika hubungan masyarakat lokal dengan perusahaan juga tampak pada sikap yang ditunjukkan dengan melakukan protes dan demonstrasi apabila lahan yang ditanami perusahaan diakui sebagai lahan leluhur. Bahkan di beberapa kecamatan terjadi penolakan terhadap keinginan beberapa perusahaan yang akan membuka perkebunan kelapa sawit. Walaupun di kecamatan lainnya, banyak juga masyarakat yang menerima program perkebunan kelapa sawit, karena mereka melihat kesuksesan masyarakat di Kecamatan Ngabang selama menjadi petani sawit.

Hubungan antara masyarakat lokal dengan "pendatang" juga ber langsung dinamis. Kadang kala hubungan antara petani plasma dengan pendatang berlangsung positif dan harmonis, juga pernah terjadi "ketegangan" antara mereka.

Misalnya, di dusun Nek Temben merupakan bagian dari Desa Amboyo Inti masyarakat saling tolong menolong dalam semua aspek kehidupan. Dusun ini dihuni oleh masyarakat yang berlatar etnik Jawa dan Dayak. Dari sisi agama umumnya beragama Kristen, Protestan dan Islam.

Keharomisan ini tampak adanya komitmen untuk saling membantu baik bantuan materi ataupun pikiran dan tenaga, misalnya pada saat perayaan pesta perkawinan dan sunnatan, semua warga terlibat dalam kepanitian dan donasi acara tersebut. Demikian juga, pada perayaan Hari Besar Agama, masyarakat yang berbeda agama dan etnik tersebut saling mengunjungi kediaman masing-masing.

Hubungan harmonis ini juga ditunjukkan dengan komitmen untuk saling membantu jika ada orang sakit di dusun tersebut, semua masyarakat membantu memfasilitasi ke rumah sakit. Bahkan area pemakaman orang yang meninggal dunia, berada pada satu kawasan, hanya dibedakan oleh model nisan untuk menunjukkan agama yang dianut.

Gagasan warga Nek Temben untuk saling membantu dalam melunasi kredit lahan sawit. Siapapun yang mendapatkan arisan diwajibakan melunasi hutang kepada pihak bank dan akan mendapatkan sertifikat tanah. 
Arisan ini digunakan sebagai media saling membantu,nilai uang yang disetor kepada penerima arisan tidak dibatasi. Dengan semangat untuk membantu sesama, anggota koperasi dibenarkan menyetor uang tidak dibatasi angkanya. Anggota bisa menyetor 1 juta, 3, sampai 5 juta kepada anggota yang memperoleh giliran mendapat arisan. Namun, anggota tersebut memiliki kewajiban untuk membayar nilai uang yang sama pada saat anggota lainnya memperoleh giliran mendapatkan arisan.

Tabel

Rumah Ibadah dan lembaga lainnya Wilayah PTPN XIII

\begin{tabular}{|c|c|c|c|c|c|c|c|c|c|}
\hline & & \multicolumn{7}{|c|}{ Afdeling/Bagian } \\
\cline { 3 - 10 } No & Lembaga & 1 & 2 & 3 & 4 & 5 & 5 A & Emplas & Jml \\
\hline 1 & Masjid & 1 & 1 & 1 & 1 & 1 & - & 1 & 6 \\
\hline 2 & Gereja & - & - & - & - & - & - & 1 & 1 \\
\hline 3 & Taman Kanak2 & - & - & - & - & - & - & 1 & 1 \\
\hline 4 & Penitipan Bayi & 1 & 1 & 1 & 1 & 1 & - & - & 5 \\
\hline 5 & Poliklinik & - & - & - & - & - & - & 1 & 1 \\
\hline 6 & Kamar mandi Umum & 2 & 4 & 3 & 5 & 3 & - & - & 17 \\
\hline
\end{tabular}

Sumber: Data Olahan tahun 2014

Peristiwa "konflik" perusahaan dengan masyarakat lokal juga pernah terjadi di lokasi perkebunan. Pada tahun 2000 perusahaan memanfaatkan lahan yang tidak diperuntukkan untuk sawit.Masyarakat lokal melakukan demonstrasi kepada perusahaan dengan tuntutan bahwa lahan yang digunakan untuk tanaman sawit tersebut merupakan tanah adat yang tidak boleh ditanami. Akibatnya, PTPN XIII harus membayar denda adat sejumlah Rp. 3 juta.

Peristiwa lain juga terjadi, pada tahun 2006 Pada saat perusahaan menanam bibit sawit di lahan lahan HGO masyarakat lokal juga menuntut pihak perusahaan untuk membayar denda. Tuntutan ini membuat perusahaan harus membayar Rp. 40 juta.

Beberapa peristiwa perselisihan antara masyarakat lokal dan pihak PTPN XIII menjelaskan bahwa pembukaan lahan perkebunan kelapa sawit di Kecamatan Ngabang "ibarat api dalam sekam". Potensi "konflik" antara perusahaan dan masyarakat lokal sangat terbuka dan akan terus membesar.

Masyarakat lokal yang "mengklaim" lahan perkebunan sawit sebagai lahan leluhur juga masih sering terjadi. Mereka merasa "kehilangan" tanah karena diklaim oleh PTPN. Hal ini terjadi di berbagai lokasi perkebunan. Bahkan di beberapa kecamatan di Ngabang terjadi penolakan pembukaan lahan untuk perkebunan kelapa sawit.

\section{Peran Lembaga Adat}

Sejarah berdirinya atau dibentuknya kampung Dayak sebagai tempat tinggal kelompok, bermula dibukanya lahan untuk berladang. Dalam pembukaan lahan berikutnya, hanya didirikan pondok-pondok saja untuk tempat tinggal sementara. Waktu tertentu, seperti pesta panen (naik dangou), orang Dayak pulang ke kampung halaman mereka, rumah betang.

Rumah betang ini memiliki fungsi beragam, misalnya sebagai tempat tinggal, media komunikasi diantara kelompok, tempat pertahanan dari serangan kelompok lain, dan menghindari serangan binatang buas.

Nama-nama kampung, umumnya diadopsi dari nama-nama tokoh masyarakat yang 
dinilai memiliki kelebihan atau kesaktian sebagai bentuk penghargaan atau sebagai simbol status kampung tersebut. Inspirasi nama kampung juga diambil dari nama-nama yang bersumber dari alam, misalnya nama pohon yang ditemukan pertama kali, atau nama sungai, atau nama gunung dan sebagainya.

Peran lembaga atau tokoh adat Dayak sangat besar dalam mengontrol termasuk sistem ekologi yang ada di sekitar mereka. Setiap pergantian musim selalu diiringi dengan ritual-ritual adat. Pada saat pembukaan lahan untuk berladang dan ditanami padi, tokohtokoh adat yang akan memimpin ritual tersebut. Proses menanam padi, hingga musim panen tokoh masyarakat memiliki peran yang sangat besar. Pesta panen (naik dangau) merupakan perayaan bagi warga masyarakat untuk mengucapkan syukur kepada Jubata (Tuhan), yang diwujudkan dalam bentuk ritual adat.

Peran lembaga atau tokoh adat juga sangat besar dalam kehidupan di tingkat keluarga dan sosial masyarakat. Tumenggung, pasirah dan tokoh adat lainnya bertanggung jawab untuk memimpin pada proses perkawinan, hingga kematian.

Dalam kehidupan sosial, tokoh adat tersebut juga terlibat dalam mengatur hubungan sosial masyarakat. Misalnya, jika terjadi perkelahian di dalam kelompok atau dengan kelompok lain, tokoh adat memainkan peran sebagai "juru damai" diantara pihak yang berseteru.

Perubahan pola hidup orang Dayak dalam pertanian padi menjadi perkebunan karet dan sawit memunculkan dampak sosial yang sangat mengkhawatirkan.

Pertama, orang Dayak kehilangan identitas mereka. Perayaan pesta panen padi (Naik Dangou) sudah berubah hanya untuk kepentingan pariwisata, bukan lagi untuk kepentingan spiritualitas orang Dayak itu sendiri. Orang Dayak yang menanam padi sudah sangat sedikit karena jenis tamanan padi mulai diganti dengan tanaman lain, termasuk karet dan sawit.

Perubahan pola tanam ini juga menyebabkan berubahnya sosial ekonomi orang Dayak. Dalam aspek ekonomi, banyak orang Dayak yang memiliki penghasilan yang cukup baik karena harga karet dan sawit di pasaran dunia cukup tinggi. Permintaan karet dan $\mathrm{CPO}^{7}$ dari negara-negara maju dan kebutuhan dalam negeri juga sangat tinggi.

Hal ini berdampak, di Kabupaten Landak membuka perkebunan sawit, walaupun juga ada masyarakat lokal yang menentang. Generasi muda muda Dayak lebih tertarik untuk menanam sawit dari pada menanam padi.

Dengan penghasilan yang cukup tinggi memunculkan kelas sosial baru dalam masyarakat lokal. Awalnya banyak orang Dayak hanya menanam hanya cukup untuk memenuhi kebutuhan keluarga dan tidak untuk dijual. Sementara untuk memenuhi kebutuhan lainnya, mereka mengandalkan hasil sadapan karet, semakin banyak getah karet yang diperoleh maka akan mendapatkan banyak uang. Namun jika musim hujan tiba, orang Dayak tidak bisa menyadap karet, otomatis tidak mampu memenuhi kebutuhan rumah tangga mereka. Bahkan banyak juga yang harus berhutang hanya untuk membeli rokok, minyak goreng, dan kebutuhan lainnya.

Munculnya kelas sosial ini telah merubah gaya hidup orang Dayak. Umumnya mereka tidak lagi tinggal di rumah betang dan mendirikan rumah di tengah kota. Artinya, hubungan kekerabatan diantara kelompok sudah mulai pudar, karena jarak rumah tinggal antara satu dengan lainnya sudah berjauhan.

Generasi muda Dayak di kota sudah tidak lagi mempercayai cerita-cerita dari orang tua dan leluhur mereka. Sumber informasi yang dahulu diperoleh dari budaya lisan diganti dengan budaya modern seperti handphone, televisi, koran, internet dan media sosial lainnya.

7 Data negara-negara penghasil karet dan sawit tersesar di dunia 
Bahkan generasi baru ini menilai cerita-cerita dari nenek moyang hanyalah cerita masa lalu dan tidak lagi dibutuhkan saat ini. Anak cucu mereka lebih mengenal tokoh-tokoh film dunia, tokoh kartun, tokoh politik dan tidak mengenal tokoh-tokoh Dayak masa lalu.

Beberapa perkampungan orang Dayak, fungsi lembaga dan tokoh adat masih menunjukkan eksistensinya. Misalnya, warga Desa Semade Kecamatan Banyuke Hulu menolak terhadap berdirinya perusahaan perkebunan kelapa sawit di wilayah mereka. Penolakan ini dilakukan oleh pemuda dan masyarakat di desa tersebut atas dasar jejak pendapat yang dilakukan pada tanggal 19 Agustus 2014 bertepat di gedung SD Negeri 06 Semade.

Pernyataan penolakan ini ditanda tangani oleh Tumenggung adat desa Semade, Paulinus Bibi, Gabungan kelompok tani Desa Semade, Moses serta beberapa tokoh masyarakat. Penolakan ini dilatar belakangi oleh adanya kecemasan masyarakat terhadap ekspansi perusahaan yang sudah merambah hutan lindung dan hutan konversi serta hutan produktif diubah status dan fungsinya menjadi kepala sawit. Jika perusahaan membuka lahan sawit tanpa memperhatikan hal tersebut maka akan merusak lingkungan, dan air sebagai nafas bagi masyarakat lokal (Pontianak Post, Kamis, 4 September 2014).

Fakta lain juga menunjukkan bahwa keberadaan lembaga adat masyarakat lokal juga masih dipelihara oleh orang Dayak di Kembayan. Tumenggung bersama tokoh adat masyarakat setempat merespon tingginya tingkat kriminalitas khususnya pencurian hasil panen sawit di wilayah Kembayan. Mereka memutuskan hukuman adat bagi pencuri yang melakukan kriminalitas karena dalam kondisi tidak ada pilihan misalnya, karena kemiskinan, kelaparan maka akan dikenakan denda adat 3 tail ${ }^{8}$. Sedangkan jika masyarakat menangkap pencuri hanya untuk memperkaya diri dan untuk kesenangan, maka akan didenda adat dengan cara membayar uang sebesar 6 tail atau Rp. 1,8 juta. Jika pelaku tidak sanggup atau tidak bersedia membayar denda adat, maka tumenggung akan menyerahkan kasus tersebut kepada pihak berwajib (polisi).

Dua kejadian ini berada pada wilayah pedesaan (pedalaman) jauh dari pusat kota Landak (Ngabang). Catatan penting peristiwa ${ }^{9}$ ini adalah, mulai munculnya kesadaran masyarakat di beberapa tempat untuk mempertahankan sisa-sisa peninggalan leluhur mereka $^{10}$.

\section{Perubahan Ekonomi Masyarakat}

1.Ladang berpindah menjadi Perkebunan Inti Rakyat (PIR)

Perubahan ladang berpindah menjadi perkebunan kelapa sawit di Kalimantan Barat merupakan kelanjutan dari program pemerintah Republik Indonesia bersama bank dunia.

8 setiap 1 tali jika ditukar dengan uang rupiah Rp. 300.000 .

9 Informasi dari berbagai sumber yang diperoleh dari penelitian ini menjelaskan bahwa tidak semua respon masyarakat adat terhadap keberadaan perusahaan karet dan sawit murni kesadaran untuk mempertahankan eksistensi lembaga dan tokoh adat atau ekologi di pedalaman. Beberapa peristiwa demonstrasi masyarakat di Kabupaten Landak terhadap perusahaan sarat dengan muatan politik lokal. Banyak tokoh politik lokal yang memiliki perkebunan sawit sendiri, namun tidak memiliki pabrik. Pihak manajemen pabrik PTPN pernah di tegur oleh politisi di Kabupaten Landak hanya soal antrian mobil angkut sawit (truk) yang sangat panjang karena persoalan teknis. Setelah diusut ternyata diantara truk yang mengantri tersebut ada sawit miliknya.

10 Pada tahun 2000an Pihak manajemen kebun Ngabang juga pernah di demo oleh sekelompok masyarakat yang mengataskan namakan perwakilan lembaga adat. Persoalannya adalah, pihak manajemen menanami lahan PTPN (inclub - tanah kosong) untuk ditanami sawit. Namun masyarakat mengklaim bahwa tanah tersebut adalah milik adat. Akibatnya, perusahaan dikenai sanksi adat dengan membayar Rp. 3,5 juta dan lahan yang lain Rp. 40 juta. 
Perkebunan kelapa sawit sudah dibuka di pulau Kalimantan, Riau, Sumatera Selatan dan lainnya.

Pada awal dibukanya perkebunan tersebut, PTPN XIII menggunakan konsep PIR (Perkebunan Inti Rakyat). Artinya, perusahaan tidak hanya mengutamakan kepentingan membesarkan dan mencari keuntungan semata namun juga membantu masyarakat lokal untuk mandiri secara ekonomi.

Konsep perkebunan Inti dimaksudkan bahwa dalam pengelolaan perkebunan sawit, perusahaan dapat memperoleh keuntungan (profit). Sedangkan konsep Rakyat (PIR) dimaknai bahwa perusahaan memiliki tanggung jawab untuk memberdayakan ekonomi masyarakat lokal.

Konsep ini merupakan pelaksanaan dari Instruksi Presiden (Inpres) nomor 1 tahun 1986 tanggal 3 Maret 1986 tentang Pengembangan Perkebunan dengan Pola perusahaan inti rakyat yang dikaitkan dengan program transmigrasi.

Pola ini dimaksudkan pelaksanaan pengembangan perkebunan dengan menggunakan perkebunan besar sebagai inti yang membantu dan membimbing rakyat di sekitarnya sebagai plasma dalam suatu sistem kerja sama yang saling menguntungkan, utuh dan berkisambungan.

Perkebunan inti adalah perkebunan besar lengkap dengan fasilitas pengolahannya yang dibangun (dikembangkan) dan dimiliki oleh perusahaan inti dalam rangka pelaksanaan proyek PIR.

Wilayah plasma adalah wilayah pemukiman dan wilayah usaha tani yang dikembangkan oleh petani dalam rangka pelaksanaan proyek PIR yang meliputi pekarangan, perumahan dan kebun plasma.

Kebun plasma adalah areal wilayah plasma yang dibangun oleh perusahaan inti dengan tanaman perkebunan. Sedangkan petani peserta proyek PIR adalah petani yang ditetapkan sebagai penerima pemilikan kebun plasma dan berdomisili di wilayah plasma.

PIR diatur bahwa dalam pembukaan kawasan perkebunan kelapa sawit harus terintegrasi antara kepentingan perusahaan dalam memperoleh keuntungan (profit) dengan kemandirian ekonomi masyarakat.

Pola kerja sama antara masyarakat dan pihak pemerintah diwujudkan dengan pembagian lahan perkebunan. Luas lahan perkebunan yang disediakan masing-masing petani peserta yakni lahan perkebunan plasma $2 \mathrm{~h}$, lahan pekarangan, termasuk tapak perumahan $0,50 \mathrm{~h}$.

Setiap Kepala Keluarga akan memperoleh lahan perkebunan 1 kapling sawit terdiri dari 2 Hektar untuk lahan perkebunan untuk ditanami sawit; 0,2 Hektar (200m2 untuk pekarangan) dan $0,3 \mathrm{H}$ (300m2 untuk lahan perumahan).

Kerja sama antara pemerintah (perusahaan yang ditunjuk dalam hal ini PTPN XIII) dengan masyarakat (petani karet) dilakukan dengan membagi hak dan kewajiban antara keduanya. Perusahaan (PTPN XIII di Ngabang) diwajibkan membangun perkebunan inti lengkap dengan fasilitas pengolahannya yang dapat menampung hasil perkebunan inti dan perkebunan plasma.

Kondisi perkebunan inti di PTPN XIII dilengkapi dengan berbagai fasilitas seperti membangun pabrik pengolahan kelapa sawit menjadi CPO. Sedangkan bagi perkebunan plasma, PTPN XIII juga membangunkan rumah bagi petani dilengkapi dengan pekarangan.

PTPN XIII melaksanakan pembangunan perkebunan plasma sesuai dengan petunjuk operasional dan standar fisik yang ditetapkan oleh Departemen pertanian cq. Dirjen Perkebunan. Tidak diperkenankan perusahaan ini mengambil kebijakan diluar ketentuan yang sudah digariskan oleh pemerintah, mulai dari awal tanam, pemupukan hingga panen 
sawit.

PTPN XIII juga bertindak sebagai pelaksana penyiapan lahan pekarangan dan pembangunan perumahan petani peserta. Perkebunan sawit di Ngabang yang diperuntukkan untuk masyarakat (petani plasma) sebanyak $2 \mathrm{~h}$ selalu dilengkapi dengan rumah tinggal dan pekarangan.

Pada saat pembukaan lahan perkebunan sawit, masyarakat tidak mengerti sistem perkebunan, sudah terbiasa ladang berpindah. Perusahaan bekewajiban membina secara teknis para petani peserta agar mampu mengusahakan perkebunan dengan baik. Sejak dibukanya perkebunan, perusahaan yang bertugas mulai menebang hutan, menanam bibit sawit, memberi pupuk dan perawatan hingga 3 tahun. Memasuki tahun keempat petani plasma diberi kewenangan untuk mengelola lahan sawitnya sendiri, hingga pelaksanaan panen sawit

Petani plasma tidak diperkenankan untuk menjual hasil panen sawitnya kepada pabrik milik perusahaan lain kecuali hanya kepada pabrik yang dikelola oleh PTPN XIII. Perusahaan ini berkewajiban untuk menampung (membeli) hasil kebun plasma dengan harga yang layak sesuai dengan pedoman yang ditetapkan oleh pemerintah (Menteri Pertanian).

Distribusi lahan perkebunan kelapa sawit dari PTPN ke masyarakat lokal juga diikuti hak dan kewajiban kedua belah pihak. Pihak perusahaan akan bertanggung jawab terhadap perkebunan inti dan plasma, yakni tanggung jawab membuka lahan perkebunan, menanam bibit sawit, memupuk, meracun hama selama tiga tahun. Memasuki tahun keempat lahan plasma tersebut dikelola oleh masyarakat lokal (setiap KK) hingga panennya. Sedangkan kewajiban setiap kepala keluarga adalah diberi tanggung jawab untuk melunasi biaya operasional yang dilakukan perusahaan.

Namun saat ini, selain PTPN XIII, hadir juga perusahaan swasta yang memiliki pabrik ada di Ngabang. Kabupaten Landak saat ini sudah berdiri dan beroperasi perusahaan sawit Willmar di Pahuman, dan SMS di Sebangki. Dalam beberapa tahun ke depan juga akan beroperasi 4 perusahaan lainnya yakni PT. IGP di Ngabang, PT. SSS di Ngabang, PT. LIP di Jelipo, PT. Wilmar 2 di Ngabang dan PT. DMS di Ngabang.

Diprediksi kondisi jual beli sawit di Ngabang akan mengalami nasib yang sama seperti perusahaan sawit milik pemerintah di Kalimantan Timur. Masyarakat lokal (petani plasma) yang mau menjual hasil panen sawitnya kepada pihak pemerintah dan lebih memilih menjual kepada pabrik swasta. Alasan mereka sangat pragmatis, karena pihak swaswa membayar hasil sawit mereka dengan cara cash bukan credit seperti PTPN. Walaupun dari sisi harga jual pihak PTPN berbeda tipis dengan pihak swasta.

Kondisi ini mirip yang terjadi di Ngabang. Petani plasma ada yang secara sembunyisembunyi menjual sawitnya kepada swasta, dengan argumentasi yang sama yakni soal harga yang lebih tinggi dan pembayaran dilakukan dengan cash dan kredit. Namun pada saat harga jual sawit di swasta rendah, dan PTPN XIII tinggi, petani plasma berbondong-bondong menjual hasil panen sawitnya ke pabrik milik pemerintah.

Kewajiban PTPN lainnya yakni membantu proses pelaksanaan pengembalian kredit petani peserta. Lahan $2 \mathrm{~h}$, setiap petani plasma berkewajiban membayar kredit kepada bank dari segala biaya yang dikeluarkan oleh pemerintah.

Awalnya, PTPN membuka lahan perkebunan besar diperuntukkan bagi 3 kalangan, transmigran yang ditetapkan oleh Menteri transmigrasi, namun khusus di perkebunan sawit di Ngabang tidak ada transmigran yang diikutsertakan oleh Pemerintah.

Kedua, lahan diperuntukkan bagi penduduk setempat termasuk para petani yang terkena proyek bersangkutan yang ditetapkan oleh Pemerintah Daerah, dan petani (peladang) berpindah dari kawasan hutan terdekat yang dikenakan untuk proyek. 
Sejak awal proyek perkebunan sawit di Ngabang hanya diperuntukkan bagi penduduk di sekitar wilayah PTPN XIII dan petani ladang yang berpindah. Namun dalam perjalanan dari tahun ke tahun, masyarakat lokal yang berladang mengalami ketidakpercayaan terhadap masa depan sawit. Hal ini disebabkan pola tanam padi dengan sawit berbeda. Sawit memerlukan perawatan dengan waktu panen yang sangat lama (tahun ke 3). Pada tahun 1980an, harga jual sawit masih rendah dan tidak mampu mencukupi kebutuhan petani plasma.

Hal-hal inilah mendorong masyarakat lokal (petani plasma) di Ngabang menjual lahan perkebunan sawit kepada pihak lain. Yang menarik adalah lahan-lahan sawit tersebut dijual kepada "pendatang". Umumnya yang membeli lahan tersebut karyawan PTPN XIII yang berasal dari pulau Jawa dan Sumatera Utara serta orang Dayak dari Sompak (Pahoman), Batang Tarang, orang Tionghoa.

Pada tahun 1986, untuk memudahkan pembayaran dengan sistem kredit tersebut, PTPN membentuk koperasi yang diberi nama koperasi "Sama Bangun". Tugas koperasi ini adalah memfasilitasi pembayaran angsuran kredit dari masyarakat (pemilik lahan perkebunan sawit).

Di beberapa lokasi perkebunan sawit masyarakat lokal yang awalnya menerima program pemerintah ini. Namun tidak mudah untuk merubah pola ladang berpindah masyarakat lokal kepada perkebunan sawit.

Dalam pandangan masyarakat lokal banyak sekali kesulitan yang dihadapi dalam pengelolaan dan pemeliharaan kebun kelapa sawit. Mulai dari siklus atau waktu setiap tahapan, dari pemeliharaan, pemupukan, hingga panen. Semuanya berbeda dengan sistem berladang.

Persoalan teknis ini semakin rumit ditambah dengan harga jual buah kelapa sawit tidak menentu, fluktuatif. Espektasi masyarakat lokal terhadap hasil perkebunan sawit tidak terwujud pada saat itu. Bahkan harga jual buah kelapa sawit ini mencapai angka terendah yakni hanya Rp. 200 perkilo. Pasti, pemilik tidak akan memperoleh keuntungan!.

Fakta-fakta ini memunculkan kekecewaan masyarakat lokal terhadap program PIR, janji kemandirian dan keuntungan ekonomi tidak diraih. Di beberapa bagian (afdeling) perkebunn sawit, banyak masyarakat lokal yang menjual lahannya kepada para pendatang, baik orang Dayak dari Pahuman, Batang Tarang, dan lainnya. Terbatasnya pembeli, membuat masyarakat lokal juga menjual kaplingnya kepada karyawan PTPN XIII. Pada saat ini, banyak ditemukan lahan perkebunan sawit milik masyarakat lokal (plasma) sudah berpindah tangan menjadi milik karyawan PTPN XIII' ${ }^{11}$.

Gelombang penjualan perkebunan plasma sawit ini terjadi sebelum masa reformsi (1998/1999). Hal ini disebabkan jatuhnya harga sawit dunia yang juga berdampak terhadap masyarakat lokal pemilik lahan sawit tersebut.

Banyak sekali penjelasan yang dikemukakan oleh berbagai pihak, seperti pemilik lahan sawit (orang Dayak pendatang maupun karyawan PTPN XIII). Alasan masyarakat lokal menjual lahan sawitnya, pertama, secara psikologi, orang Dayak merasa pola perkebunan sawit hanya memberikan kepuasan materi saja (jika harga jualnya mahal), namun tidak memiliki kepuasan psikologis, menikmati keindahan dan kenyamanan sebagaimana pola perladangan padi dan karet. Orang Dayak mengikuti proses tumbuh kembangnya padi, mulai dari bibit, tumbuh dengan warna hijau, menguning hingga panen.

Kedua, pola ladang berpindah, secara ekonomi tidak memerlukan modal usaha dan

11 Berdasarkan informasi dari berbagai pihak menyebutkan bahwa karyawan PTPN XIII tidak diperkenankan memiliki dengan cara membeli atau lainnya lahan perkebunan PIR. Namun peneliti belum menemukan aturan yang menjelaskan larangan tersebut. 
ketergantungan atau beban kepada pihak lainnya. Orang Dayak yang sering ladang berpindah tidak dibebankan untuk membeli pupuk untuk tanaman. Mereka juga tidak dibebankan hutang sebagaimana pola PIR dengan bayaran sistem kredit. Ketiga, perkebunan sawit setelah program PIR, membuat orang Dayak harus bekerja keras mulai dari membuka lahan, menanam benih sawit, memupuk dan selanjutnya ${ }^{12}$.

Salah seorang Kepala Dusun di kawasan perkebunan, merupakan orang Dayak yang berasal dari Desa Sompak Pahoman bersama 6 orang yang berasal dari tempat yang sama, membeli lahan sawit dari orang Dayak Ngabang, Lahan ini dibeli dengan harga Rp. 200 ribu pada tahun 1992. Beliau membangun kembali rumah permanen.

Alasan pemilik lahan menjual kebun kelapa sawit, disebabkan lokasi lahan sawit jauh dari tempat tinggalnya, pemilik meninggalkan keluarga besar yang berada di kampung asal, umumnya mereka tidak sanggup lagi mengelola lahan sawit tersebut karena tidak memiliki latar peengatahuan tentang seluk beluk kelapa sawit.

Pemilik lahan di bagian (afdeling 10) 90\% pemiliknya sudah berpindah tangan kepada pendatang (Dayak dari Kecamatan atau Kabupaten lainnya) dan beberapa juga dibeli oleh karyawan PTPN XIII.

Pembelian lahan sawit masyarakat lokal juga dilakukan oleh karyawan PTPN XIII (SB) memmbeli lahan sawit dengan masyarakat lokal seharga Rp. 8 juta. Saat ini sertifikat dibalik nama pembeli dengan biaya Rp. 2,5 juta.

Menjelang pensiun, ia membeli tanah kaplingan $(15 \mathrm{mx} 30 \mathrm{~m})$ dari seharga Rp. 15 juta. Lahan ini awalnya untuk perkebunan kepala sawit, namun karena letaknya dipinggir jalan dialih fungsikan menjadi perumahan.

\section{Ekonomi Kelompok Masyarakat Lokal}

Sejak dulu, masyarakat lokal yang berdomisili di Kecamatan Ngabang umumnya bekerja di ladang dengan cara berladang di bukit-bukit. Umumnya orang-orang Dayak yang berdomisili di pedalaman Kalimantan Barat hidup seperti orang Dayak di wilayah lainnya. Selain bekerja dan mencari nafkah dengan cara berladang (menanam padi di gununggunung), untuk menghidupi padi berharap dari air hujan dan tidak ada irigasi.

Berbeda dengan pola pertanian di pulau Jawa, masyarakatnya menanam padi di sawah dan sumber airnya dari irigasi. Pola seperti ini sudah berlangsung lama hingga kini. Hingga tahun 2012, luas lahan sawah yang dimiliki oleh masyarakat hanya berjumlah 72.872 hektar (12,93\%).

Selain bekerja di sektor pertanian (ladang), sejak tahun 1980an, sebagian masyarakat lokal beralih ke tanaman sawit sebagai sumber penghasilan. Masyarakat lokal juga bekerja di sektor bukan tanah sawah atau di area perkebunan. Dilihat dari kuantitasnya, pada tahun 2012, luas tanah bukan sawah 490.805 hektr $(87,07 \%)$.

Dari jumlah tersebut, pengguna lahan bukan sawah paling luas digunakan untuk area perkebunan yaitu sebesar 212.191 hektar (43,23\%), kemudian hutan rakyat seluas 111.425 hektar (22,70\%), dan tegal/kebun sebesar 74.254 (15,13\%).

Untuk menopang kebutuhan rumah tangga, masyarakat juga mengembangkan industri kecil, menengah dan koperasi. Industri kecil ini meliputi kerajinan tangan berupa

12 Cerita yang dikemukakan oleh Simon Salim, salah satu inisiator pendirian koperasi Sama Bangun bahwa orang Dayak di Ngabang tidak mengerti prosesi perkebunan sawit. "saya pernah menyaksikan ketika PTPN membagikan pupuk kepada masyarakat loka untuk sawit mereka, karena alasan ketidaktahuan, dan rumit untuk dikerjakan karena luasnya kebun sawit, banyak diantara mereka membuang pupuk tersebut ke Sungai. Ada juga sebagian yang mengerti harga pupuk tersebut, kemudian menjualnya kepada pihak lain. 
anyaman yang terbuat dari rotan dan sumber daya alam lainnya.

Meningkatnya pendapatan masyarakat di Kecamatan Ngabang, juga diikuti bertambahnya jumlah kendaraan baik roda dua maupun roda empat. Peningkatan kendaraan juga diimbangi dengan dibukanya usaha bengkel mobil dan motor di daerah ini. Jenis usaha ini paling banyak digeluti hingga menembus angka 227 buah.

Usaha lain yang dikerjakan oleh masyarakat lokal adalah penggilingan padi yang berumlah 50 buah. Usaha jenis tidak berskala besar, karena padi yang dihasilkan hanya cukup untuk memenuhi kebutuhan masyarakat lokal, bahkan hanya dikonsumsi sendiri.

Sejak dibukanya lahan perkebunan kelapa sawit pada tahun1980an, banyak masyarakat yang beralih menekuni usaha kelapa sawit. Walaupun dalam perjalanannya mengalami pasang surut, dengan gelombang penjualan lahan perkebunan sawit oleh masyarakat lokal kepada karyawan PTPN XIII dan "pendatang” lainnya.

Hingga saat ini, belum ada penelitian yang secara khusus menghitung kepemilikan mayarakat lokal terhadap lahan perkebunan kelapa sawit. Informasi yang peneliti peroleh menjelaskan bahwa banyak masyarakat lokal yang menjual lahan perkebunan kelapa sawit yang dibagikan oleh PTPN XIII. Mereka lebih memilih kembali mencari nafkah dengan cara berladang dan menanam karet. Peningkatan pendapatan masyarakat di Kecamatan Ngabang sesungguhnya lebih banyak dinikmati oleh "pendatang" dari pada masyarakat lokal (Dayak) di Kecamatan Ngabang. Beberapa peristiwa gelombang penjualan lahan kelapa sawit terjadi di afdeling 10 dan 11.

Sensus penduduk tahun 2012, menyajikan data kemiskinan di wilayah Kabupaten Landak. Gambaran penduduk miskin di Kalimantan Barat pada tahun 2012 sebagaimana tabel :

Tabel

Jumlah Penduduk Miskin dan Indikator Kemiskinan Menurut Kabupaten/Kota

Tahun 2012

\begin{tabular}{|l|l|l|l|l|l|l|}
\hline No & \multicolumn{1}{|c|}{ Kabupaten } & $\begin{array}{c}\text { Jml } \\
\text { Penduduk } \\
(\mathbf{0 0 0})\end{array}$ & \multicolumn{1}{|c|}{ PO } & \multicolumn{1}{|c|}{ P1 } & P2 & $\begin{array}{c}\text { Garis } \\
\text { Kemiskinan }\end{array}$ \\
\hline 1. & Kab. Sambas & 44.50 & 8.88 & 1.12 & 0.22 & 266.047 \\
\hline 2. & Kab. Bengkayang & 14.90 & 6.74 & 1.02 & 0.26 & 239.006 \\
\hline 3. & Kab.Landak & 41.30 & 12.41 & 1.47 & 0.30 & 250.608 \\
\hline 4. & Kab.Pontianak & 13.30 & 5.64 & 0.78 & 0.19 & 236.107 \\
\hline 5. & Kab.Sanggau & 18.30 & 4.40 & 0.55 & 0.09 & 219.441 \\
\hline 6. & Kab.Ketapang & 52.00 & 11.91 & 2.18 & 0.64 & 297.647 \\
\hline 7. & Kab.Sintang & 31.60 & 8.55 & 1.24 & 0.35 & 327.666 \\
\hline 8. & Kab.Kapuas Hulu & 22.50 & 9.95 & 1.70 & 0.49 & 290.026 \\
\hline 9. & Kab.Sekadau & 10.90 & 5.93 & 0.52 & 0.07 & 225.498 \\
\hline 10. & Kab. Melawi & 22.00 & 12.10 & 2.55 & 0.79 & 346.694 \\
\hline 11. & Kab.Kayong Utara & 9.90 & 10.16 & 1.15 & 0.20 & 211.207 \\
\hline 12. & Kab. Kubu Raya & 31.90 & 6.27 & 0.65 & 0.14 & 263.525 \\
\hline 13. & Kota Pontianak & 32.50 & 5.77 & 0.66 & 0.14 & 310.707 \\
\hline 14. & Kota Singkawang & 10.10 & 5.32 & 0.80 & 0.24 & 309.567 \\
\hline
\end{tabular}




\begin{tabular}{|l|l|l|l|l|l|l|}
\hline & Kalbar 2012 & 355.70 & 7.96 & 1.24 & 0.33 & 239.162 \\
\hline & Kalbar 2011 & 376.12 & 8.48 & 1.47 & 0.39 & 219.636 \\
\hline & Kalbar 2010 & 400.41 & 9.10 & 1.38 & 0.33 & 211.902 \\
\hline
\end{tabular}

Sumber: landak Dalam Angka, 2013

Keterangan:

PO: Persentase kemiskinan

P1: Kedalaman Kemiskinan

P2: Keparahan Kemiskinan

Dari jumlah penduduk 413.000 jiwa, persentase kemiskinan (PO) berjumlah 12.42. Kedalaman kemiskinan di wilayah ini mencapai angka 1.47, sedangkan tingkat keparahan menembus angka 0,30. Sedangkan garis kemiskinan di Kabupaten Landak berjumlah 250.608 .

Fakta ini menunjukkan sisi yang berbeda dari hiruk pikuk bisnis sawit di Kecamatan Ngabang khsusunya dan Kabupaten Landak umumnya. Dibalik pertumbuhan ekonomi dan peningkatan pendapatan masyarakat di wilayah ini, sesungguhnya menyisakan fakta lain yakni msih banyak di bawah garis kemiskinan.

\section{Ekonomi Kelompok Masyarakat "Pendatang"13}

Sejak dibukanya perkebunan kelapa sawit pada tahun 1980an, pemerintah lebih mengutamakan distribusi lahan sawit (plasma) kepada masyarakat lokal di Ngabang. Walaupun dalam Inpres No. 1 tahun 1986 tanggal 3 Maret 1986 memberikan ruang yang sama kepada pendatang (transmigran) untuk mengelola perkebunan kelapa sawit dengan pola PIR.

Pertumbuhan ekonomi di Ngabang tidak dapat dipisahkan dari pengaruh orang-orang "luar Kalimantan Barat" seperti orang Jawa, Sumatera Utara dan masyarakat dari Kabupaten lainnya. Awalnya, ekonomi masyarakat lokal hanya dihasilkan dari berladang saja, namun dalam perjalananya masyarakat lokal mulai mengenal karet dan sawit.

Perubahan pola dari ladang berpindah menjadi karet dan sawit secara ekonomi sangat berpengaruh terhadap pemilik ladang Awalnya masyarakat lokal memiliki espektasi yang tinggi terhadap perkebunan sawit akan merubah ekonomi mereka. Namun sejak tahun 1998/1999, gelombang penjualan terjadi, karena masyarakat lokal kecewa sawit tidak mampu mengangkat dan memperbaiki ekonominya.

Keterbatasan pengetahuan tentang seluk beluk tanaman sawit sawit dan perubahan pola ladang ke sawit menjadi alasan masyarakat lokal menjual lahan sawitnya. Masyarakat lokal terbatas dalam relasi dengan masyarakat pendatang dan hanya mengenal karyawan PTPN XIII, menjadi alasan menjual lahan sawit mereka kepada karyawan. Selain karyawan, pembeli lahan sawit juga masyarakat yang datang dari kabupaten lainnya, seperi Sanggau, Sintang dan lainnya.

Karyawan PTPN XIII umumnya orang Jawa dan Sumatera Utara membeli lahan

13 Kata "pendatang" digunakan dalam bahasan ini hanya untuk memberikan pembeda dengan masyarakat lokal. Pendatang yang dimaksud adalah para pegawai PTPN XIII yang berasal dari provinsi Jawa Tengah, Jawa Timur dan Jawa secara umum. Pendatang yang bekerja di PTPN juga berasal dari Sumatera Utara. Ada juga pendatang dari lokal yakni beberapa kabupaten di Kalimantan Barat seperti Kabupaten Sanggau, Sintang, dan lainnya. 
sawit dengan alasan bahwa masyarakat lokal menelantarkan perkebunan sawit mereka dan harga jual lahan yang murah mendorong mereka membeli lahan tersebut.

Saat ini, perkebunan sawit selain selain milik masyarakat lokal Ngabang, juga banyak dimiliki oleh karyawan PTPN XIII, mulai dari 2 hektar hingga 10 hektar, bahkan ada yang lebih.

\section{Sukses "Pendatang" di Ngabang}

Sukses masyarakat Ngabang dampak dari perkebunan sawit, dikisahkan . karyawan tetap di PTPN XIII. Tahun 2009-2010, bapak tiga orang anak ini "blukar", memperjualbelikan tanah milik masyarakat lokal seluas 2 hektar dengan harga Rp. 450 juta. Dengan modal nekat, kemudian ia menggagas untuk menjual lahan ini dengan cara dikapling (petak). Satu petak dengan ukuran $15 \mathrm{mx} 30 \mathrm{~m}$, dan dihargai perpetak Rp. 13 juta. Ternyata, penjualan lahan dengan cara ini banyak diminati oleh masyarakat dari berbagai kalangan, seperti pegawai negeri sipil, kepolisian, TNI, pegawai kabupaten, dan tidak ketinggalan pendatang dengan profesi lainnya. Setelah memjual semua lahannya dengan cara cash, pak Mari dapat membayar harga lahan 2 hektar tersebut.

Saat ini, ia sudah mampu menjual 16 hektar lahan sawit yang dikapling untuk pemukiman penduduk. Dari keuntungan bisnis jual beli lahan sawit untuk perumahan hingga tahun 2014, ia sudah mampu membeli dan membangun tiga buah rumah, satu digunakan untuk tempat tinggal, dan dua lainnya dikontrakkan.

"Pendatang" sukses lainnya adalah TLB merupakan laki-laki asal Sumatera Utara. Pada tahun 1984, dia melamar kerja di perusahaan dan ditempatkan sebagai kerani kebun. Namun gaji bulanan tidak cukup memenuhi kebutuhan keluarga kecilnya. Rasa cinta dan keinginan untuk membahagiakan anak dan istrinya, dia mengembangkan bisnis ternak ayam daging. Inisiatif ini muncul karena banyaknya rumah makan sepanjang jalan di Kecamatan Ngabang hingga Sanggau, namun kekurangan daging ayam.

Pelan tapi pasti, pada tahun 1990 membuka peternakan ayam di kawasan tempat tinggalnya, yakni di atas kolam. Permintaan daging ayam terus meningkat dia membuka peternakan ayam di beberapa tepat yang berbeda. Hal ini dimaksudkan jika kandang pertama diserang penyakit, maka tidak akan menular ke kandang lainnya.

Bahkan pada tahun 2010, mampu menjual ayam daging hingga menembus angka 8500 ekor yang tersebar di 40 kandang yang dimilikinya di sepanjang Pahuman hingga Sanggau. Ia mampu memasarkan kepada pelanggannya 10 rumah makan. Usaha ini terus berkembang, krena di wilayah Ngabang belum ada yang beternak ayam, tidak ada saingan.

Kesuksesan beternak ayam sudah diraih, kemudian mengembangkan ikan di dalam kolam untuk memanfaatkan kotoran ayam. Bahkan kotoran ayam yang semakin banyak diformulasi untuk pupuk kepala sawit. Belum ada masyarakat di Ngabang yang menggunakan pupuk dari kotoran ayam seperti dia.

Pada tahun 2012, ia mengajukan permohonan pensiun dini dari PTPN XIII, dan tidak mampu lagi membagi waktu untuk bekerja di perusahaan sawit. Hingga saat ini sudah memiliki 350 hektar lahan kepala sawit. Luasnya lahan sawit yang dimiliki dan bisnis jual beli ayam daging, telah merubah ekonomi keluarga inti dan masyarakat di sekitarnya tempatnya berusaha.

Kisah sukses lainnya PA. Beliau adalah orang Dayak berasal dari Pahoman. Di tanah kelahirannya, beliau adalah petani ladang yang berpindah-pindah dan karet. Pada tahun 1990, beliau datang ke Ngabang karena ada tawaran untuk membeli lahan perkebunan sawit milik petani plasma.

Tidak mudah meninggalkan kampung halaman, berpindah rumah berarti 
meninggalkan tanah kelahiran. Namun dorongan untuk meningkatkan pendapatan ekonomi keluarga "memaksa" beliau "merantau" ke Ngabang sebagai petani sawit.

Alasan membeli lahan sawit ini karena harga jual sawit relatif stabil. Yang kedua, hasil dari perkebunan karet tidak menjanjikan, karena sangat tergantung dari kondisi alam. Pada musim panas, karet akan menghasilkan banyak getah, namun kebahagian petani karet akan hilang, jika musim hujan tiba, apalagi intensitas hujan tinggi. Apabila perubahan cuaca ini tidak menentu, petani mengalami kehidupan yang serba sulit. Hasil karet akan berkurang, dan tidak akan mampu menghidupi ekonomi keluarga mereka. Dengan alasan itu, ia memutuskan untuk membeli lahan petani karet dari masyarakat lokal di Ngabang.

Dalam perjalananya, beliau memperoleh informasi bahwa lahan sawit di Afdelingnya tidak semuanya dimiliki oleh masyarakat lokal lagi, banyak diantara mereka menjual lahannya kepada karyawan dan "pendatang" lainnya, walaupun masih ada yang dimiliki masyarakat lokal (penduduk dusun Jamai).

\section{Alih Fungsi Lahan Kebun Sawit}

Konsep awal dibukanya lahan perkebunan kelapa sawit yang dilakukan oleh PTPN XIII dengan masyarakat adalah Perkebunan Inti Rakyat (PIR). Pada lahan perkebunan tersebut ada bagian yang dikelola oleh PTPN dan sebagian lainnya di kelola oleh masyarakat (plasma).

Konsep plasma memberikan hak kepada petani sawit untuk memiliki dan mengelola lahan seluas 2 hektar, juga diberikan lahan dan rumah untuk tempat tinggal. Pola ini mengintegrasi antara perkebunan dan pemukiman, agar petani sawit lebih mudah bekerja.

Namun, konsep integrasi ini sudah banyak yang berubah. Petani tetap menggarap kebunnya, namun mereka tidak lagi berdomisili di lahan dan rumah yang dibangun oleh perusahaan. Peneliti menemukan di dusun Mak Temben, Afdeling 11, dari 264 KK yang memiliki lahan sawit hanya tersisa $35 \mathrm{KK}$ yang menempati lahan dan rumah ${ }^{14}$ yang dibangun perusahaan.

Perubahan fungsi ini dalam beberapa bentuk, lahan perkebunan dibeli dan dibangun perumahan (komplek), dibeli dan dikembangkan sebagai lokasi bisnis seperti rumah toko (ruko), bengkel.

Lahan sawit yang sudah dibeli kemudian kembangkan dengan cara dikapling untuk dibangun perumahan dengan ukuran 15mx30m. Pada tahun 2010 harga 1 kapling lahan perumahan Rp. 15 juta, namun tahun 2014 ini harganya sudah mencapai Rp. 50 juta dengan posisi lahan jauh dari jalan raya. Jika posisi lahan di pinggir jalan harga 1 kapling seharga Rp. 100 juta lebih.

Pihak pemerintah daerah Kabupaten Nlandak dan PTPN XIII tidak dapat berbuat banyak dengan melarang transaksi ini. Lahan yang dijual oleh masyarakat ke pihak lain merupakan lahan yang sudah dimiliki dengan bukti sertifikat tanah.

Seiring perjalanan waktu, saat harga jual kelapa sawit semakin membaik, banyak masyarakat yang tidak lagi menjual lahan perkebunan sawitnya kepada pihak lain dan berupaya mengelola lahan tersebut agar menghasilkan buah yang bagus.

\section{Penutup}

14 Rumah-rumah yang dibangun oleh PTPN sejak tahun 1980 sudah banyak yang tidak dapat difungsikan lagi karena lapuk dimakan rayap. Hal ini terjadi karena bahan yang digunakan untuk membangun rumah tersebut terbuat dari kayu (papan). Dari 35 rumah yang tersisa, semuanya sudah direhab atau dibangun rumah baru oleh pemilik lahan. Sedangkan petani sawit lainnya memilih untuk pindah domisili dan membangun rumah tinggal di luar perkebunan kelapa sawit. 
Pembukaan perkebunan kelapa sawit 30 tahun yang lalu, telah merubah masyarakat lokal pada aspek sosial. Perubahan tersebut terjadi pada semua dimensi kehidupan masarakat, terjadinya individualisasi masyarakat adat yang kental dengan konsep kekerabatan, tergerusnya peran lembaga adat, hilangnya budaya lisan yang diganti dengan budaya pop.

Perkembunan kelapa sawit pada sisi ekonomi telah mampu menigkatkan pendapatan masyarakat di Ngabang. Namun pembukaan perkebunan sawit dengan konsep inti dan rakyat (plasma) "jauh panggang dari api". Kesejahteraan ekonomi lebih banyak dinikmati oleh "pendatang" dari pulau Jawa, Sumatera Utara, dan masyarakat dari kabupaten lainnya. Masyarakat lokal hanya menikmati sebagian kecil dari manisnya sawit, lebih banyak menonton dari pada pelaku.

\section{DAFTAR PUSTAKA}

Amrizal. 1987. Elastisitas Pendapatan terhadap Permintaan Minyak Goreng Kelapa di Kalimantan Timur. Balai Penelitian Kelapa Manado. BALITKA. p.83-84.

Anon. 1987. Perbanyak Vegetatif Kelapa Sawit Dengan Kultur Jaringan Produksi Dalam Negeri. Buletin Warta Pertanian. (April-Mei) (no. 54) p. 18.

-. 1988. Mengecambahkan Dolar di Kebun Sawit . Buletin Informasi Pertanian Bengkulu. V.2 (001) p.12-13.

-------. 1989. Pembangunan Perkebunan Dengan Pola PIR-BUN di Provinsi Bengkulu. Buletin Informasi Pertanian Bengkulu. V.2 (001) p.16-19.

Chairan. 1991. Teknik Pengadaan Benih Kelapa Sawit. Berita Penelitian Perkebunan. V.1 (2). P.57-70 3 ill; 4 ref.

Chaniago, F. 1988. Masalah Pemakaian Diagnosis Daun pada Perkebunan Kelapa Sawit di Indonesia. Buletin Pertanian. Fakultas Pertanian Universitas Islam Sumatera Utara. V.7 (1) p. 16-24 8 ref; tables.

Daswir D dan Abbas. 1984. Beberapa an itu Faktor Yang Mempengaruhi Usaha Budidaya Kelapa Sawit Ex Proyek Pengembangan Perkebunan Rakyat Sumatera Utara. Buletin Penelitian Perkebunan Medan. Vol. 15 (1).p 31-37.

Hasni H; Torar DJ dkk. 1987. Survey Pabrik Minyak Kelapa di Sulawesi Utara . Balai Peneliti Kelapa Manado. BALITKA p.80-82 No. 12.

Ian Craib. 1994. Modern Social Theory : From Parson to Habermas. (Terj). Jakarta: PT. Raja Grafindo Persada.

Kosasih. 1988. Pengaruh Dolimit dan Kisiriet Terhadap Pertumbuhan dan Kandungan Metabolit Bibit Sawit Jenis Dumpy Dura X Pisifera Umur Enam Bulan. Buletin Pertanian. Fakultas Pertanian Universitas Islam Sumatera Utara. V.7 (1) p. 7-9 ref .

Loebis B. 1986. Sifat Kimia dan Fisika Dari Fraksi Cair dan Padat Pada Minyak Sawit. Buletin Perkebunan. V.16.(3) p. 131-134 6 ref.

Lubis S, Poeloengan Z dkk. 1990. Potensi dan Peningkatan Produksi Kelapa Sawit. Pusat Penelitian dan Pengembangan Tanaman Industri. Bukit Tinggi 15-17 Januari, Bogor, Puslitbang 22.p. 23 ref.

N.J. Demarath III dan R.A, Peterson. 1967. System change and Conflict. New York: Free Press 
Pusat Perpustakaan dan Penyebaran Teknologi Pertanian. 1986. Bungkil Inti Sawit dan Ampas Minyak Sawit Sebagai Pakan Ternak/Ketaren. Warta Penelitian dan Pengembangan Pertanian. Juli-November 1986. Vol.8 (4-6) p.10-11.

Pangudijatno.1988. Sebuah Kajian Tentang Pertanaman Kelapa Sawit Pada Tanah Gambut. Buletin Pertanian. Fakultas Pertanian Universitas Islam Sumatera Utara. V.7 (1) p. 1-6, 5 tables; 10 ref.

Pardede D. 1990. Serangga Penyebuk Kelapa Sawit di Kebun Kertarahardja Lebak dan Kerjaya PIR-BUN V Banten Selatan. Buletin Perkebunan V 21 (4) p.213-223 5 tables; 9 ref.

Robert H. Lauer 2001. Perspective on Social Change. (Terj) Jakarta: PT. Rineka Cipta.

Rusmawardi Rusmawardi. 2007. Dampak Berdirinya Perkebunan Kelapa Sawit (Elaeis guineensis jack) Terhadap Kondisi Sosial Ekonomi Masyarakat (Studi Kasus Pada Desa Kabuau, Kecamatan Parenggean, Kabupaten Kotawaringin Timur, Propinsi Kalimantan Tengah). Departement of Agribisnis.

Yusriadi, Hermansyah dan Ismail Ruslan dkk (2012). Pengetahuan Tradisional Masyarakat Dayak (Studi Atas Masyarakat Benuaq di Tanjung Isuy Kalimantan Timur). Pontianak: Balai Pelestarian Nilai Budaya Pontianak.

Wilbert E. Moore .1967. Order and Chage; Essays in Comparative Sociology, New York: John Wiley\&Sons,

Wright, W. 1975. Six Guns and Society; A Structural Study of the Western. Berkeley: University of California Press. 